JURNAL SONDIR

p-ISSN 1979-2832

e-ISSN 2746-8275

https://ejournal.itn.ac.id/index.php/sondir

vol.5 No.1 Tahun 2021, pp. 7-12

\title{
PENENTUAN DIAMETER PIPA OPTIMAL DALAM PERENCANAAN SISTEM PENYEDIAAN AIR BERSIH DI KECAMATAN WONOTIRTO KABUPATEN BLITAR PROVINSI JAWA TIMUR
}

\author{
Nenny Roostrianawaty ${ }^{1}$, Sriliani Surbakti ${ }^{2}$, dan Muhammad Erfan ${ }^{3}$ \\ ${ }^{122) 3)}$ Jurusan Teknik Sipil, ITN Malang, Jl. Bendungan Sigura-gura No. 2 Malang \\ Email: nennyroos.nr@lecturer.itn.ac.id \\ Email: mohammaderfan@ftsp.itn.ac.id \\ Email: liani_surbakti@lecturer.itn.ac.id
}

\begin{abstract}
Optimization of pipe diameter in the planning of clean water supply systems in Wonotirto District aims to determine the projected demand for clean water in Wonotirto District until 2028. This research was conducted because currently the distribution of clean water in the study location is still not completely fulfilled. Topographical conditions, most of which are in mountainous areas, cause one of the reasons for the difficulty of distributing clean water. The pipe diameter optimization planning in this study uses the Hazen-William method. The data used are the population in the last 10 years, geoelectric data, and topographic maps of Wonotirto District, Blitar Regency. Based on the results of the planning, it is found that the projected number of population in 2020 is 37,013 people. the discharge of clean water needs is 63.73 liters / second, the dimensions of reservoir 1 are planned to be $6 \mathrm{~m} \mathrm{x} 4 \mathrm{~m} \mathrm{x} 3 \mathrm{~m}$, reservoir 2 is planned to be $6.5 \mathrm{~m} \mathrm{x} 4 \mathrm{~m} \times 3 \mathrm{~m}$. The type of pipe used is the type of PVC with a diameter of 0.75 inches, 1 inch, 1.25 inches, 1.5 inches, 2 inches, 2.5 inches, 3 inches, 4 inches, 6 inches, where planning calculations are carried out using the Hazen-William Method. The limited amount of groundwater discharge at the location means that not all villages in the Wonotirto District area have their clean water needs met and it is hoped that further research will improve this research.
\end{abstract}

Keywords: optimization, reservoir, geoelectric, clean water, pipe diameter

\begin{abstract}
ABSTRAK
Optimasi diameter pipa dalam perencanaan sistem penyediaan air bersih di Kecamatan Wonotirto ini bertujuan untuk mengetahui proyeksi kebutuhan air bersih di Kecamatan Wonotirto sampai dengan tahun 2028. Penelitian ini dilakukan karena saat ini distribusi air bersih di lokasi studi masih belum terpenuhi secara menyeluruh. Kondisi topografi yang sebagain besar berada di wilayah pegunungan menyebabkan salah satu penyebab sulitnya distribusi air bersih. Perencanaan optimasi diameter pipa pada penelitian ini menggunakan metode Hazen-William. Data yang digunakan adalah jumlah penduduk 10 tahun terakhir, data geolistrik, dan peta topografi Kecamatan Wonotirto Kabupaten Blitar. Berdasarkan hasil perencanaan didapatkan jumlah proyeksi penduduk pada tahun 2020 sebesar 37,013 jiwa. debit kebutuhan air bersih 63.73 liter/detik, dimensi reservoir 1direncanakan $6 \mathrm{~m} \mathrm{x} 4 \mathrm{~m}$ x $3 \mathrm{~m}$, reservoir 2 direncanakan $6,5 \mathrm{~m} \times 4 \mathrm{~m} \times 3 \mathrm{~m}$. Jenis pipa yang digunakan yaitu jenis PVC dengan diameter 0.75 inchi, 1 inchi, 1.25 inchi, 1.5 inchi, 2 inchi, 2.5 inchi, 3 inchi, 4 inchi, 6 inchi, dimana perhitungan perencanaan dilakukan dengan menggunakan Metode Hazen-William. Keterbatasan jumlah debit air tanah di lokasi menyebabkan belum semua desa yang ada di wilayah Kecamatan Wonotirto terpenuhi kebutuhan air bersihnya dan diharapkan ada penelitian lebih lanjut yang akan menyempurnakan penelitian ini.
\end{abstract}

Kata kunci: optimasi, reservoir, geolistrik, air bersih, diameter pipa

\section{PENDAHULUAN}

Pertambahan jumlah penduduk yang terus meningkat dan kondisi wilayah yang tergolong kering, menyebabkan kebutuhan air bersih di Kecamatan Wonotirto terus meningkat dan distribusinya tidak merata. Kondisi geografis Kecamatan Wonotirto merupakan dataran tinggi sehingga pemenuhan kebutuhan air bersih sehari-hari hanya mengandalkan air hujan. Hal inilah yang mendorong pemerintah daerah untuk berupaya memenuhi kebutuhan air bersih kepada masyarakat dengan membuat jaringan pipa air bersih yang diharapkan mampu untuk memenuhi kebutuhan masyarakat terutama pada musim kemarau. 
JURNAL SONDIR

https://ejournal.itn.ac.id/index.php/sondir vol. 6 No. 1 Tahun 2021, pp.

Salah satu upaya yang dilakukan untuk memperoleh air bersih adalah dengan menggunakan sumur bor dalam, dimana air dipompa menuju reservoir kemudian didistribusikan ke seluruh Kecamatan Wonotirto. Namun upaya ini masih belum bisa memenuhi seluruh kebutuhan air bersih penduduk. Tercatat masih ada beberapa desa yang belum mendapatkan layanan air bersih yaitu Desa Tambakrejo, Desa Kaligrenjeng, Desa Pasiraman, Desa Sumberboto, Desa Gununggede, Desa Ngeni, Desa Wonotirto dan Desa Ngadipuro. Untuk itu perlu dilakukan upaya optimalisasi diameter pipa sehingga diharapkan kebutuhan air bersih di beberapa desa tersebut dapat terpenuhi.

Dalam perencanaan ini perhitungan proyeksi penduduk dihitung dengan prediksi 10 tahun yang akan datang dengan menggunakan sumber air dari sumur bor dalam kemudian ditampung dalam reservoir sebelum dialirkan ke pemanfaat. Untuk itu diperlukan perhitungan dan pengukuran debit air tanag yang salah satunya dilakukan dengan menggunakan metode geolistrik, kemudian menghitung kebutuhan rencana kebutuhan pipa dan reservoir sesuai kebutuhan di lokasi.

\section{TINJAUAN PUSTAKA}

\section{Optimasi}

Optimasi atau optimalisasi adalah proses, cara dan perbuatan untuk mengoptimalkan (menjadikan paling baik, paling tinggi, dan sebagainya). Jadi, optimasi atau optimalisasi adalah sebuah proses, cara dan perbuatan (aktivitas/kegiatan) untuk mencari solusi terbaik dalam beberapa masalah yang sesuai dengan kriteria tertentu. Menurut Suprodjo dan Purwandi, 1982 dalam Tarmizi, 2005, bahwa secara matematis optimasi adalah cara mendapatkan harga ekstrim baik maksimum atau minimum dari suatu fungsi tertentu dengan faktorfaktor pembatasnya.

Menurut Peraturan Menteri Kesehatan Republik Indonesia Nomor 492/MENKES/PER/IV/2010 tentang Persyaratan Kualitas Air Minum, air minum adalah air yang melalui proses pengolahan atau tanpa proses pengolahan yang memenuhi syarat kesehatan dan dapat langsung diminum. (Permenkes RI No. 492, 2010).

Sumber air bersih bisa berasal dari:

1. Air tanah

Air tanah adalah air yang terdapat dalam lapisan tanah atau bebatuan di bawah permukaan tanah.

2. Air permukaan

Air permukaan adalah air yang berada di permukaan bumi dapat berupa air sungai, air danau, dan air laut.

3. Air hujan

Air hujan adalah air angkasa, dalam wujud lainnya dapat berupa salju

\section{Proyeksi Jumlah Penduduk}

Perhitungan perkiraan jumlah penduduk pada tahun mendatang dapat dilakukan berdasarkan angka kenaikan penduduk rata -rata setiap tahun. Perhitungan-perhitungan tersebut dapat dilakukan dengan beberapa metode:

1. Metode Aritmatika

Metode ini menganggap pertumbuhan penduduk memiliki jumlah yang sama setiap tahun.

$$
\mathrm{Pt} \quad=\mathrm{Po}(1+\mathrm{n} . \mathrm{r}) \text {. }
$$

Dimana:

$\mathrm{Pt}=$ Jumlah penduduk pada akhir periode $\mathrm{t}$ (orang)

$\mathrm{Po}=$ Jumlah penduduk pada awal periode $\mathrm{t}$ (orang)

$\mathrm{r}=$ Tingkat pertumbuhan penduduk

$\mathrm{n}=$ Jangka waktu / tahun proyeksi

2. Metode Geometrik

Metode ini menganggap pertumbuhan penduduk yang menggunakan dasar bunga majemuk. Angka pertumbuhan penduduk dianggap sama untuk setiap tahun.

$$
\mathrm{Pt}=\mathrm{Po}(1+\mathrm{r})^{\mathrm{n}} \ldots \ldots \ldots \ldots \ldots \ldots
$$

Dimana:

$\mathrm{Pt}=$ Jumlah penduduk pada akhir periode $\mathrm{t}$ (orang)

Po $=$ Jumlah penduduk pada awal periode $\mathrm{t}$ (orang)

$\mathrm{r}=$ Tingkat pertumbuhan penduduk

$\mathrm{n}=$ Jangka waktu / tahun proyeksi

3. Metode Eksponensial

Metode ini menganggap pertumbuhan penduduk secara terus menerus setiap hari dengan angka pertumbuhan konstan.

Pt $\quad=$ Po.e $e^{\mathrm{rn}}$.

Dimana:

$\mathrm{Pt}=$ Jumlah penduduk pada akhir periode $\mathrm{t}$ (orang)

Po $=$ Jumlah penduduk pada awal periode $\mathrm{t}$ (orang)

$\mathrm{r}=$ Tingkat pertumbuhan penduduk

$\mathrm{n}=$ Jangka waktu / tahun proyeksi

$\mathrm{e}=2,71828183$ (bilangan eksponensial)

\section{Kebutuhan Air Bersih}

Kebutuhan air bersih ini meliputi kebutuhan air domestik dan non domestik. Kebutuhan domestik yaitu kebutuhan skala rumah tangga sedangkan kebutuhan non domestik yaitu kebutuhan di luar skala rumah tangga dan biasa lebih kepada keperluan untuk fasilitas umum. Selain kebutuhan air bersih pada perhitungan perencanaan kebutuhan air bersih perlu juga diperhitungkan faktor kehilangan air, yaitu Besarnya niali kehilangan air tersebut berkisar antara 20-30 \% dari total kebutuhan air bersih domestik maupun non domestik.

\section{Debit Air Tanah}

Debit air tanah yang dibutuhkan pada penelitian ini dihitung dengan menggunakan alat geolistrik.

$$
\begin{aligned}
& Q=K . A . i \ldots \ldots \ldots \ldots \ldots \ldots \ldots(4) \\
& A=\frac{1}{4} \cdot \Pi \cdot d^{2} \cdot b
\end{aligned}
$$


JURNAL SONDIR

p-ISSN 1979-2832

e-ISSN 2746-8275

https://ejournal.itn.ac.id/index.php/sondir

vol. 6 No. 1 Tahun 2021, pp.

Dimana:

$\mathrm{Q}=$ Debit air tanah $\left(\mathrm{m}^{3} /\right.$ hari $)$

$\mathrm{A}=$ Luas akuifer $\left(\mathrm{m}^{2}\right)$

$\mathrm{d}=$ Diameter sumur (m)

$\mathrm{b}=$ Ketebalan akuifer $(\mathrm{m})$

$\mathrm{i} \quad=$ Landaian hidrolika akuifer

$\mathrm{K}$ = Nilai kelulusan air (m/hari)

\section{Perhitungan Perencanaan Pipa}

Perhitungan perencanaan dimensi pipa dihitung menggunakan Rumus Hazen Wiliam karena rumus ini sudah memasukkan unsur jenis pipa, kehilangan pada pipa, baik major losses maupun minor losses. Secara umum Rumus Hazen William adalah sebagai berikut :

$$
\mathrm{v}=0,354 \times \mathrm{C}_{\mathrm{H}} \times \mathrm{I}^{0.54} \times \mathrm{D}^{0.63} .
$$

Dimana :

$\mathrm{v}=$ Kecepatan aliran $(\mathrm{m} / \mathrm{d})$

$\mathrm{C}_{\mathrm{H}}=$ Koefisien Hazen-William

$\mathrm{D}=$ Diameter pipa $(\mathrm{m})$

$\mathrm{I}=$ Kemiringan garis energi

$\mathrm{h}_{\mathrm{f}}=$ Mayor losses $(\mathrm{m})$

$$
\mathrm{I}=\frac{h_{f}}{\mathrm{~L}}
$$

$\mathrm{L}=$ Panjang pipa dari node $1-2(\mathrm{~m})$

\section{Jenis Pipa}

Ada beberapa macam jenis pipa yang sering digunakan dalam perencanaan perpipaan distribusi air bersih dan pada penelitian ini digunakan pipa jenis PVC. Karakteristik PVC adalah bebas dari korosi, ringan, sehingga mempermudah dalam pengangkutan, mudah dalam penyambungan, dan mempunyai umur relatif lama selain itu harganya lebih murah dibandingkan dengan jenis pipa yang lain.

\section{Pompa}

Dalam permasalahan distribusi air bersih, tidak terlepas dari kemungkinan penggunaan pompa. Berdasarkan pada Pedoman Penyusunan Perancangan Teknis Pengembangan Sistem Penyediaan Air Minum 2007, debit pompa distribusi ditentukkan berdasarkan fluktuasi pemakaian air dalam satu hari. Pompa harus mampu mensuplai debit air jam puncak dimana pompa besar yang bekerja dan saat pemakaian minimum pompa kecil yang bekerja. Debit pompa besar ditentukan sebesar 50\% dari debit puncak. Pompa kecil sebesar $25 \%$ dari debit jam puncak.

\section{Reservoir}

Reservoir merupakan bangunan penampung air baku atau air bersih sebelum didistribusian kepada pelanggan atau masyarakat. Fungsi dari reservoir yaitu untuk mengumpulkan air, menyimpan air, meratakan aliran, meratakan tekanan aliran dan menyimpan air untuk seluruh konsumen atau pengguna dan pemadam kebakaran. Kapasitas reservoir ditentukan berdasarkan pemakaian air perjam selama satu hari, dengan memperhitungkan surplus maksimum dan defisit minimum, dan juga berdasarkan kebutuhan air untuk pemadam kebakaran dan lamanya pemompaan.

\section{METODOLOGI}

Data-data yang digunakan dalam penelitian ini antara lain :

1. Data jumlah penduduk 10 tahun terakhir

2. Data kebutuhan air

3. Data geolistrik

4. Peta topografi

Perencanaan desain jaringan pipa distribusi dihitung berdasarkan debit kebutuhan yang telah dihitung sebelumnya dan jenis pipa yang digunakan yaitu pipa PVC dengan kapasitas maksimum tekanan $12 \mathrm{~kg} / \mathrm{m}$. Adapun langkah-langkah penyelesaian sebagaimana tergambar pada diagram alir berikut.

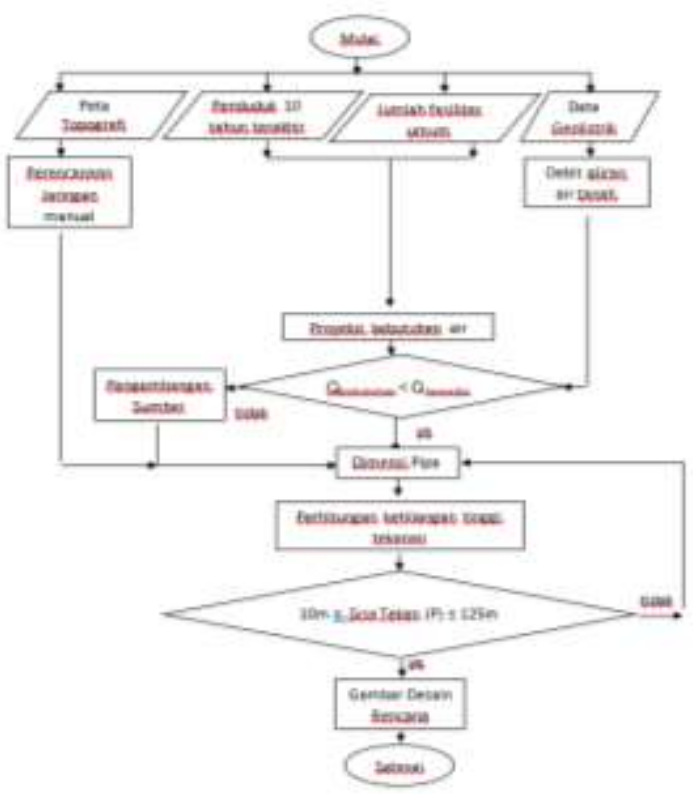

Gambar 1. Bagan alir proses penelitian

\section{ANALISA DATA DAN PEMBAHASAN}

\section{Perhitungan Proyeksi Jumlah Penduduk}

Perhitungan jumlah penduduk dilakukan dengan menggunakan 3 metode dan kemudian dicari nilai standar deviasi yang paling rendah untuk menentukan metode mana yang akan dipilih.

Perhitungan kebutuhan air untuk Kecamatan Wonotirto sebagai berikut (sesuai ketentuan dan berdasarkan jumlah penduduk Kab. Blitar termasuk golongan Kota Kecil) :

a. Jumlah penduduk terlayani

Jumlah penduduk terlayani $=$ Cakupan Pelayanan (90\%) x jumlah penduduk setiap blok 
JURNAL SONDIR

p-ISSN 1979-2832

e-ISSN 2746-8275

https://ejournal.itn.ac.id/index.php/sondir

vol. 6 No. 1 Tahun 2021, pp.

Contoh Perhitungan: (Blok A1)

Jumlah penduduk terlayani $=90 \% \times 1107=996$ jiwa

b. Konsumsi unit sambungan rumah (SR)

$\mathrm{SR}=$ Jumlah penduduk terlayani $\times 70 \% \times 100$

Contoh Perhitungan: (Blok A1)

$\mathrm{SR}=996 \times 70 \% \times 100$

$=69722.45$ liter $/$ hari

$=0.81$ liter/detik

c. Konsumsi unit hidran umum (HU)

$\mathrm{HU}=$ Jumlah penduduk terlayani $\mathrm{x} 30 \%$ x 30

Contoh Perhitungan: (Blok A1)

$\mathrm{HU}=996 \times 30 \% \times 30$

$=8964.32$ liter $/$ hari

$=0.10$ liter/detik

d. Kehilangan air

Kehilangan air $=25 \% \times(\mathrm{SR}+\mathrm{HU})$

Contoh Perhitungan: (Blok A1)

Kehilangan air $=25 \% \times(0.81+0.10)$

$$
=0.23 \text { liter/detik }
$$

Perhitungan kebutuhan air non dometsik dilakukan berdasarkan data jumlah fasilitas umum yang ada di lokasi penelitian sebagaimana tabel berikut :

Tabel 1.Jumlah Fasilitas Umum Kec. Wonotirto 2014

\begin{tabular}{|c|c|c|c|c|c|c|c|c|}
\hline \multirow{2}{*}{ Deit } & \multicolumn{8}{|c|}{ 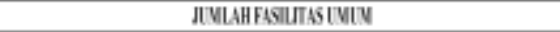 } \\
\hline & Selvet & Poluswes & Nolak: & Mas & Melabe & Genep & Vilin & Poir \\
\hline TAУEAKRED & 6 & , & . & 1 & II & 1 & . & 1 \\
\hline RALGSENEXG & 5 & . & - & 1 & 4 & - & . & 1 \\
\hline PASBANAN & 7 & . & 1 & 4 & $T$ &. &. &. \\
\hline МУВЕВОГО & $?$ & . & 1 & $\uparrow$ & 1 & $\cdot$ & $\cdot$ & 1 \\
\hline GINXGXED & $?$ & . & . & 9 & 14 & 1 & . & . \\
\hline XGADPLDO & 8 & . & 1 & 3 & 1 & 1 & . & . \\
\hline XGEXI & 22 & $\cdot$ & 1 & $\pi$ & 21 & 2 & $\cdot$ & 1 \\
\hline AONOTIKTO & H & 1 & . & 9 & 33 & . & . & . \\
\hline JINL내 & 76 & 1 & 4 & 52 & 104 & 5 & 1 & 4 \\
\hline
\end{tabular}

Berdasarkan data ini kemudian dihitung proyeksi kebutuhan untuk 10 tahun mendatang sesuai dengan proyeksi jumlah penduduk yang ada sehingga didapatkan data jumlah perkiraan fasilitas umum Kec. Wonotirto untuk tahun 2028 sebagai berikut :

Tabel 2. Jumlah Fasilitas Umum Kec. Wonotirto 2028

\begin{tabular}{|c|c|c|c|c|c|c|c|c|}
\hline \multirow{2}{*}{ DESG } & \multicolumn{8}{|c|}{ 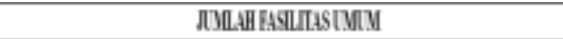 } \\
\hline & Stable & Probsers: & Pinles & Masil & Natub & Geręi & Itan & hom \\
\hline TAQALKEEO & 6 & . & $\cdot$ & 3 & 11 & 1 & . & 1 \\
\hline BALEPENENG & 5 & . & . & 1 & 4 & . & . & 1 \\
\hline PASRAYAN & 7 & $\cdot$ & 1 & 4 & 9 & $\cdot$ & $\cdot$ & $\cdot$ \\
\hline SМЕE\$OTO & 7 & - & 1 & 7 & 7 & . & - & 1 \\
\hline GNWGate & 7 & 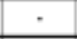 & $\cdot$ & 9 & IH & 1 & - & $\cdot$ \\
\hline NGEDPR30 & 8 & . & 1 & 3 & 7 & 1 & . & $\cdot$ \\
\hline NEN & $n$ & - & 1 & ]s & 21 & 2 & - & 1 \\
\hline HOWOIKTO & 14 & 1 & $\cdot$ & 9 & 3 & $\cdot$ & $\cdot$ & $\cdot$ \\
\hline туцин & $\pi$ & 1 & 4 & 5 & 14 & 5 & 0 & 4 \\
\hline
\end{tabular}

Setelah dilakukan perhitungan jumlah fasilitas maka selanjutnya dihitung besarnya kebutuhan debit untuk masing-masing fasilitas umum kebutuhan domestik. Contoh perhitungan sebagai berikut :
Contoh Perhitungan: (Tambakrejo)

Debit Sekolah

Jumlah murid tahun 2015 (Tambakrejo) $=660$

Populasi tahun $2015=35.580$ jiwa

Populasi tahun $2028=37.013$ jiwa

Banyak murid tahun $2028=\frac{660}{35.580} \times 37.013$

Banyak murid tahun 2028

$=\frac{\text { jumlah murid } 2015}{\text { populasi tahun } 2015} \times$ popupasi tahun 2028

Banyak murid tahun $2028=687$ jiwa

Debit Sekolah Tambakrejo = Banyak murid tahun 2028 x $10=687$ x $10=6870$ liter $/$ hari $=0.08$ liter/detik Dengan cara yang sama maka kita dapat menghitung debit kebutuhan non domestic fasilitas umum lainnya, sebagaimana tabel berikut.

Tabel 3. Debit Fasilitas Umum Kec. Wonotirto 2028

\begin{tabular}{|c|c|c|c|c|c|c|c|c|c|}
\hline \multirow{2}{*}{ DESS } & \multicolumn{8}{|c|}{ DERThSUISLEITI (ti) } & \multirow{2}{*}{ rvesa } \\
\hline & Selatat & Pnisran & Muln & Mapd & Nalida & Gaxp & Iun & Bnir & \\
\hline THQAXIEO & 6016 & (ivi) & 13 & 0.11 & 0.19 & Hil & $d x$ & $d \theta$ & 4.41 \\
\hline MLFEEIEN & 669 & 60 & $t$ & 06 & 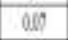 & UD & 20 & 00 & 0.15 \\
\hline PHSBANA & 60 & (i) & 13 & 0.14 & Q12 & IDI & $a x$ & $\mathrm{OMN}$ & 234 \\
\hline TSBE30X & 006 & iD & BII & 03 & 012 & 15in & 09 & 00 & Qu \\
\hline GXOXKeE? & 606 & (11) & (9) & 031 & 021 & UII & $0 . x$ & ad & M! \\
\hline 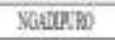 & 016 & fin & 811 & 0.11 & 6.12 & ㅂiा & 00 & 600 & 29 \\
\hline YEXY] & 0.16 & 10 & BII & 065 & (936 & if & 20 & $m$ & LI \\
\hline TOEOEXPO & 0.12 & $\mathrm{BL}$ & 80 & 031 & 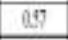 & 190 & ex & 001 & tot \\
\hline xNLA & Eili & U! & 185 & 191 & 121 & $w$ & ix & ats & 46 \\
\hline THIS & \multicolumn{9}{|c|}{32} \\
\hline
\end{tabular}

\section{Perhitungan Debit Tersedia}

Dalam studi ini analisa debit tersedia dilakukan dengan menghitung debit air tanah dari data geolistrik. Cara yang digunakan sebagai berikut:

\section{Kedalaman akuifer 1 dan akuifer 2}

1. Ketebalan Akuifer

Ketebalan Akuifer GL 1 = Selisih Kedalaman Akuifer Gl 1

$$
=113-49
$$$$
=64 \mathrm{~m}
$$

Ketebalan Akuifer GL 2 = Selisih Kedalaman Akuifer Gl 2

$$
=102-37
$$$$
=65 \mathrm{~m}
$$

1. Menghitung Nilai Kelulusan Air

$$
\begin{aligned}
& \mathrm{K}(\mathrm{GL} 1)=\frac{k \times b}{b}=\frac{12 \times 64}{64}=12 \\
& \mathrm{~K}(\mathrm{GL} 2)=\frac{k \times b}{b}=\frac{12 \times 65}{65}=12
\end{aligned}
$$

2. Menghitung Debit Aliran Air Tanah

$\mathrm{A}=\frac{1}{4} x \Pi x d^{2} \times b=\frac{1}{4} x \Pi x 1.2^{2} \times 64.5=72.918 \mathrm{~m}^{2}$

$\mathrm{Q}=\mathrm{K} \times \mathrm{A} \times \mathrm{i}=12 \times 72.918 \times 1.2=1050 \mathrm{~m}^{3} / \mathrm{hari}$ $=0.01 \mathrm{~m}^{3}$ detik $=12.2$ liter $/$ detik

3. Menghitung Debit Aliran Air Tanah $\mathrm{A}=\frac{1}{4} x \Pi x d^{2} \times b=\frac{1}{4} x \Pi x 1.2^{2} \times 64.5=72.918 \mathrm{~m}^{2}$ $\mathrm{Q}=\mathrm{K} \times \mathrm{A} \times \mathrm{i}=12 \times 72.918 \times 1.2=1050 \mathrm{~m}^{3} / \mathrm{hari}$ $=0.01 \mathrm{~m}^{3}$ detik $=12.2$ liter/detik 


\section{JURNAL SONDIR \\ p-ISSN 1979-2832 \\ e-ISSN 2746-8275}

https://ejournal.itn.ac.id/index.php/sondir

vol. 6 No. 1 Tahun 2021, pp.

\section{Kedalaman akuifer 3 dan akuifer 4}

\section{Ketebalan Akuifer}

Ketebalan Akuifer GL 3 = Selisih Kedalaman Akuifer G1 $3=116-48=68 \mathrm{~m}$

Ketebalan Akuifer GL 4 = Selisih Kedalaman Akuifer Gl $4=104-35=69 \mathrm{~m}$

2. Menghitung Nilai Kelulusan Air

$\mathrm{K}(\mathrm{GL} 3)=(\mathrm{k} \mathrm{x}$ b $) / \mathrm{b}=(12 \times 68) / 68=12$

$\mathrm{K}(\mathrm{GL} 4)=(\mathrm{k} \mathrm{x}$ b $) / \mathrm{b}=(12 \times 69) / 69=12$

3. Menghitung Debit Aliran Air Tanah

$$
\begin{aligned}
\mathrm{A} & =1 / 4 \times \Pi \times \mathrm{d}^{\wedge} 2 \times \mathrm{b}=1 / 4 \times \Pi \times 1,2^{2} \times 68.5 \\
& =77.4324 \mathrm{~m} 2 \\
\mathrm{Q} & =\mathrm{K} \times \mathrm{A} \times \mathrm{i}=12 \times 77.4324 \times 1.3=1208 \mathrm{~m} 3 / \mathrm{hari} \\
& =0.01 \mathrm{~m} 3 / \text { detik }=13.98 \text { liter/detik }
\end{aligned}
$$

Dari hasil perhitungan didapatkan jumlah debit tersedia

\begin{tabular}{|c|c|c|c|c|}
\hline 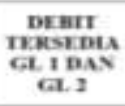 & DEss & $\begin{array}{c}\text { mok } \\
\text { stemui }\end{array}$ & $\begin{array}{l}\text { DEnr } \\
\text { Kritinas } \\
\text { mok } \\
\text { mesew }\end{array}$ & 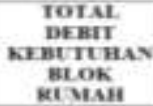 \\
\hline \multirow{14}{*}{ 12.2 aid } & \multirow{3}{*}{ Wosetitso } & Ci & a 47 ite & \multirow{14}{*}{1204 ath } \\
\hline & & $c_{2}$ & $2 \cot 10$ & \\
\hline & & C) & 0.25 arta & \\
\hline & \multirow{2}{*}{ Senthertese } & Bt & etsan & \\
\hline & & Bz & 0.4700 & \\
\hline & \multirow{7}{*}{ Poivana } & AI & 1.68 ive & \\
\hline & & A) & o.sina & \\
\hline & & $A z$ & o.esican & \\
\hline & & A & asertat & \\
\hline & & As & 0.418 & \\
\hline & & M6 & 0.95 pat & \\
\hline & & A? & acs int & \\
\hline & \multirow{2}{*}{ Kaliemining } & III & 1.22 mat & \\
\hline & & 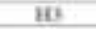 & 070 int & \\
\hline
\end{tabular}
dan debit kebutuhan sebagaimana tabel berikut :

Tabel 4. Analisa Perhitungan Kebutuhan Debit Tersedia dan Debit Kebutuhan Pada Jaringan 1

\begin{tabular}{|c|c|c|c|c|}
\hline 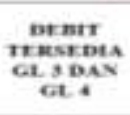 & arese & $\begin{array}{c}\text { mok } \\
\text { mexsen }\end{array}$ & 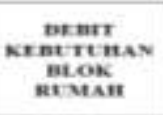 & 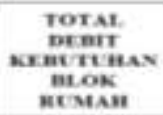 \\
\hline \multirow{20}{*}{$1200 \mathrm{tat}$} & \multirow{5}{*}{ Wrasitante } & cs & aselut & \multirow{20}{*}{13.73 bist } \\
\hline & & co & 0.20 with & \\
\hline & & $C_{7}$ & azsith & \\
\hline & & ct & 0.05 ach & \\
\hline & & $c$ & o. 00 intit & \\
\hline & \multirow{15}{*}{ Nene } & Di & 6.17 tint & \\
\hline & & Dt & i.7s buth & \\
\hline & & Di & asenith & \\
\hline & & DA & 0.71 int & \\
\hline & & Ds & 10e mat & \\
\hline & & DE & o.su anth & \\
\hline & & Do & ose ind & \\
\hline & & Die & Lazbit & \\
\hline & & Do: & Oog ath & \\
\hline & & Diz & 0.27 and & \\
\hline & & DIS & aks lach & \\
\hline & & Die & asenith & \\
\hline & & D20 & oxe bich & \\
\hline & & D21 & attitid & \\
\hline & & DzZ & ses ant & \\
\hline
\end{tabular}

Tabel 5. Analisa Perhitungan Kebutuhan Debit Tersedia dan Debit Kebutuhan Pada Jaringan 2
Dari hasil perhitungan analisa data tersebut selanjutnya dibuat perhitungan optimasi jaringan pipa dengan menggunakan beberapa variasi diameter pipa pada jaringan 1 dan jaringan 2 hingga didapatkan sisa tekan $\leq 70 \mathrm{~m}$. Hasil optimasi disajikan pada grafik berikut :

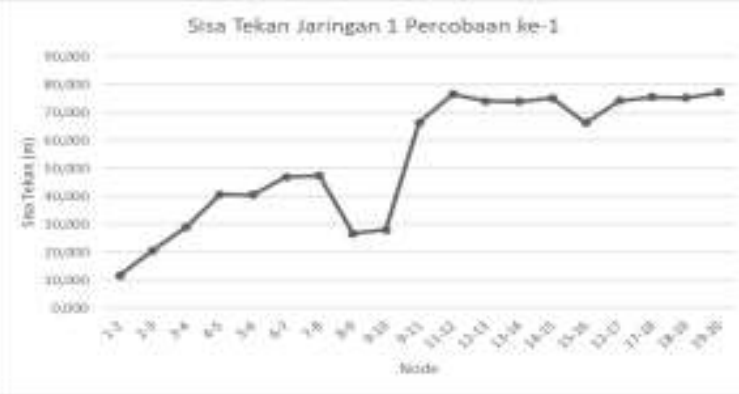

Gambar 2. Grafik Sisa Tekan Jaringan 1 Percobaan 1

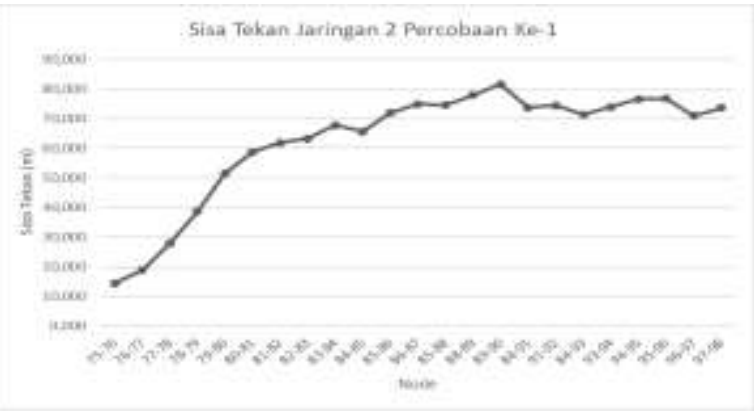

Gambar 3. Grafik Sisa Tekan Jaringan 2 Percobaan 1

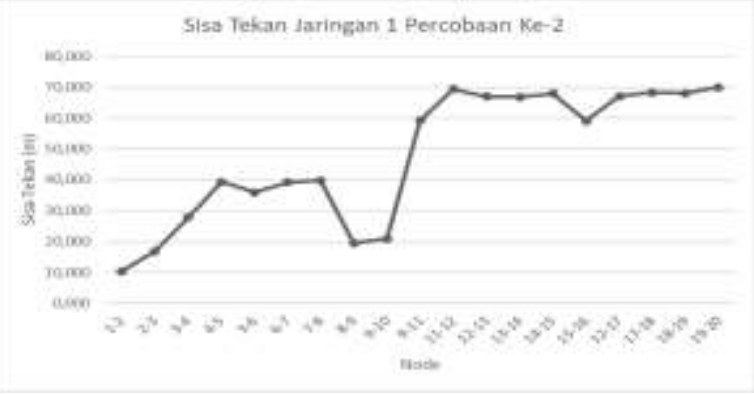

Gambar 4. Grafik Sisa Tekan Jaringan 1 Percobaan 2

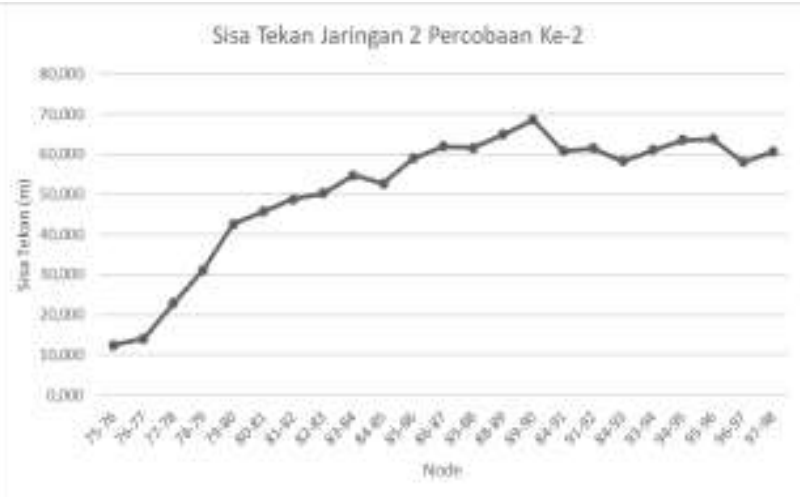

Gambar 5. Grafik Sisa Tekan Jaringan 2 Percobaan 2 
JURNAL SONDIR

https://ejournal.itn.ac.id/index.php/sondir vol. 6 No. 1 Tahun 2021, pp.

Dari ke-4 grafik tersebut dapat disimpulkan bahwa optimasi yang dapat dipakai adalah optimasi diameter pipa ke-2 karena dari hasil perhitungan sisa tekan didapatkan nilai $\leq 70$ dengan menggunakan diameter pipa yaitu 0,75 ", 1", 1.25", 1.5”, 2", 2.5”, 3", 4", 6"

\section{Perhitungan Dimensi Reservoir}

Untuk menghitung dimensi reservoir I digunakan simulasi sebagai berikut :

Kebutuhan air Harian $=12.04 \mathrm{l} / \mathrm{dt}$

Kebutuhan air Per jam $=(12.04 \times 3600) / 1000$

$$
=43.34 \mathrm{~m}^{3}
$$

Kapasitas pompa $=201 / \mathrm{dt}$

Kapasitas pompa/jam $=(20 \times 3600) / 1000=72 \mathrm{~m}^{3}$

Berdasarkan perhitungan fluktuasi debit didapatkan besarnya volume tampungan maksimum sebesar 71,14 $\mathrm{m}^{3}$. Untuk itu direncanakan dimensi reservoir sebagai berikut:

Panjang $=6 \mathrm{~m}$

Lebar $=4 \mathrm{~m}$

Tinggi $=3 \mathrm{~m}$

Volume $=6 \times 4 \times 3=72 \mathrm{~m}^{3}$ (memenuhi)

Sedangkan untuk dimensi reservoir 2 dihitung dengan simulasi sebagai berikut :

$\begin{aligned} \text { Kebutuhan air Harian } & =13.73 \mathrm{l} / \mathrm{dt} \\ \text { Kebutuhan air Per jam } & =(13.73 \times 3600) / 1000 \\ & =49.43 \mathrm{~m}^{3} / \mathrm{jam} \\ \text { Kapasitas pompa } & =201 / \mathrm{dt}\end{aligned}$

Kapasitas pompa/jam $=(20 \times 3600) / 1000=72 \mathrm{~m}^{3}$

Berdasarkan perhitungan fluktuasi debit didapatkan besarnya volume tampungan maksimum sebesar 72,16 $\mathrm{m}^{3}$. Untuk direncanakan dimensi reservoir sebagai berikut :

Panjang $=6,5 \mathrm{~m}$

Lebar $=4 \mathrm{~m}$

Tinggi $=3 \mathrm{~m}$

Volume $=6,5 \times 4 \times 3=78 \mathrm{~m}^{3}$ (memenuhi)

\section{KESIMPULAN}

Berdasarkan hasil perhitungan dan analisa data dapat disimpulkan sebagai berikut :

1. Prediksi jumlah penduduk di Kecamatan Wonotirto Kabupaten Blitar Provinsi Jawa Timur pada 10 tahun yang akan dating adalah 37013 jiwa.

2. Kebutuhan air bersih total yang diperlukan di Kecamatan Wonotirto Kabupaten Blitar Provinsi Jawa Timur adalah 63.73 liter/detik.

3. Kapasitas debit tersedia pada geolistrik 1 dan 2 adalah 12.2 liter/detik sedangkan untuk geolistrik 3 dan 4 adalah 13.98 liter/detik.
4. Dimensi pipa dan reservoir yang digunakan untuk Kecamatan Wonotirto Kabupaten Blitar Provinsi Jawa Timur adalah:

Dimensi pipa yang dipakai adalah 0.75 ", 1", 1.25",1.5", 2", 2.5", 3", 4", 6"

Dimensi Reservoir 1:

$6 \times 4 \times 3$ meter.

Dimensi Reservoir 2:

$6.5 \times 4 \times 3$ meter

Hal-hal yang harus diperhatikan dalam perencanaan adalah persiapan data yang lengkap baik data primer maupun sekunder, sehingga hasil perhitungan lebih akurat.

Ketersediaan air tanah yang terbatas perlu menjadi pertimbangan dalam penggunaannya sebagai sumber air baku karena pertumbuhan penduduk yang terus meningkat.

\section{DAFTAR PUSTAKA}

Anonim. (2018, Juni 24). Perlengkapan pipa. Diambil kembali dari sambungan pipa: https://www.jualmaterial.com/jual/fitting-pipa-teerucika-aw-berbagai-ukuran-tebal-dan-mengkilap/

Anonim. (2018, Juni 12). Threaded Hot Tapping Saddles. Diambil kembali dari http://optimq.com/en/threaded-hot-tappingsaddles/

CD Soemarto. 1987. "Hidrolika Teknik". Surabaya : Usaha Nasional

DPU Ditjen Cipta Karya. 2007. Pengembangan SPAM (Sistem Penyediaan Air Minum) Sederhana. Jakarta : Departemen Pekerjaan Umum, Direktorat Jenderal Cipta Karya. (anonim, 2018)

Maryono, Agus, W. Muth, dan N. Eisenhauer. 2002. "Hidrolika Terapan". Jakarta: PT Pradnya Paramita.

Peraturan Menteri Kesehatan RI Nomor : 492/MENKES/PER/IV/2010 tentang Syarat-Syarat Pengawasan Kualitas Air.

Sasongko, Djoko. 1985. "Teknik Sumber Daya Air". Yogyakarta : Andi Offset.

Triatmodjo, Bambang. 1993. "Hidraulika $I$ ". Yogyakarta : Beta Offset.

Tahara, Sularso Haruo. 2000. “ Pompa dan Kompresor". Jakarta : PT. Pradnya Paramita 